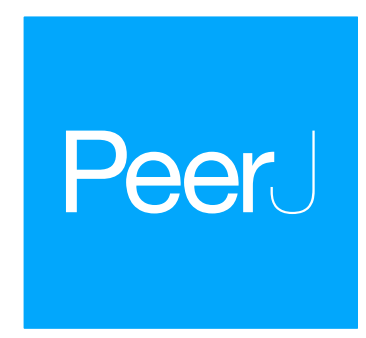

\title{
Nutrient criteria to achieve New Zealand's riverine macroinvertebrate targets
}

\author{
Adam D. Canning ${ }^{1}$, Michael K. Joy ${ }^{2}$ and Russell G. Death ${ }^{3}$ \\ ${ }^{1}$ Centre for Tropical Water and Aquatic Ecosystem Research, James Cook University, Townsville, \\ Queensland, Australia \\ ${ }^{2}$ School of Government, Victoria University of Wellington, Wellington, New Zealand \\ ${ }^{3}$ School of Agriculture and Environment, Massey University, Palmerston North, New Zealand
}

\section{ABSTRACT}

Waterways worldwide are experiencing nutrient enrichment from population growth and intensive agriculture, and New Zealand is part of this global trend. Increasing fertilizer in New Zealand and intensive agriculture have driven substantial water quality declines over recent decades. A recent national directive has set environmental managers a range of riverine ecological targets, including three macroinvertebrate indicators, and requires nutrient criteria be set to support their achievement. To support these national aspirations, we use the minimization-ofmismatch analysis to derive potential nutrient criteria. Given that nutrient and macroinvertebrate monitoring often does not occur at the same sites, we compared nutrient criteria derived at sites where macroinvertebrates and nutrients are monitored concurrently with nutrient criteria derived at all macroinvertebrate monitoring sites and using modelled nutrients. To support all three macroinvertebrate targets, we suggest that suitable nutrient criteria would set median dissolved inorganic nitrogen concentrations at $\sim 0.6 \mathrm{mg} / \mathrm{L}$ and median dissolved reactive phosphorus concentrations at $\sim 0.02 \mathrm{mg} / \mathrm{L}$. We recognize that deriving site-specific nutrient criteria requires the balancing of multiple values and consideration of multiple targets, and anticipate that criteria derived here will help and support these environmental goals.

Submitted 8 February 2021

Accepted 12 May 2021

Published 31 May 2021

Corresponding author

Adam D. Canning,

adam.canning@jcu.edu.au

Academic editor

Mario Brauns

Additional Information and Declarations can be found on page 13

DOI 10.7717/peerj.11556

(c) Copyright

2021 Canning et al.

Distributed under

Creative Commons CC-BY 4.0

OPEN ACCESS
Subjects Ecology, Zoology, Freshwater Biology, Natural Resource Management, Environmental Impacts

Keywords Eutrophication, Nutrient enrichment, Rivers, New Zealand, Macroinvertebrates, Nutrient criteria, Nutrient limits, Nitrogen, Phosphorus

\section{INTRODUCTION}

Nutrient enrichment is a key stressor of waterway health across the globe, and is largely driven by population growth, increased fertilizer application and intensive agriculture (Kahiluoto et al., 2014; Nash et al., 2017; McDowell et al., 2020a). Nutrient enrichment can drive excessive algal and microbial growth, which can relieve energy, nutrient and macromolecule growth constraints further up the food web, altering the biological communities (Elser et al., 2000; Benstead et al., 2009; Ferreira et al., 2015; Dodds \& Smith, 2016). While autochthonous production by algae can increase the total energy pool available, microbes can condition nutrient-poor detritus, making organic matter more palatable to detritivores, thus enabling another energy source that can also alter biological 
communities (Elser et al., 2000; Benstead et al., 2009; Ferreira et al., 2015; Dodds \& Smith, 2016). In more extreme cases, excessive respiration rates attributed to high autotrophic production, high decomposition rates and altered biological communities can result in hypoxic conditions that drive die-off events, such as mass fish kills, or metabolic toxicity of aquatic organisms (Ferreira et al., 2015; Le Moal et al., 2019; Wurtsbaugh, Paerl \& Dodds, 2019; Canning \& Death, 2021). Furthermore, experimental nutrient enrichment studies have observed altered ecological communities by permitting the growth of nutrient-limited invertebrates (Kiffney \& Richardson, 2001; Cross et al., 2006; Demi et al., 2018).

Macroinvertebrate growth can be limited by ambient nutrient concentrations as they typically have little flexibility (i.e., show strong homeostasis) to adjust body nutrient stoichiometry to accommodate environmental limitations (Elser et al., 2000; Persson et al., 2010; Hessen et al., 2013). Nitrogen limitation can arise from the need to replace nitrogen-rich chitin from moulting exoskeletons and produce protein and nucleic acids (Elser et al., 1996; Frainer et al., 2016). Whilst phosphorus limitation can arise from protein synthesis as this requires P-rich ribosomal RNA (Gillooly et al., 2005; Hessen, Ventura \& Elser, 2008; Hessen et al., 2013). Furthermore, the phosphorus content, specific growth rate, DNA and RNA content typically negatively correlate with body size (Elser et al., 2000; Gillooly et al., 2005; Hessen et al., 2013). Nutrients can also limit growth by constraining the availability of macromolecules, such as sterols, essential amino acids and fatty acids provided by nutrient-limited microbes (Mueller-Navarra, 1995; Goedkoop, Demandt \& Ahlgren, 2007; Wacker \& Martin-Creuzburg, 2012; Guo et al., 2016). Furthermore, experimental nutrient enrichment studies have observed altered ecological communities by permitting the growth of nutrient-limited invertebrates (Kiffney \& Richardson, 2001; Cross et al., 2006; Demi et al., 2018). For example, Cross et al. (2005) experimentally enriched a detritus-based pristine stream for two years. Whilst there was no growth effect on the stoneflies, the growth rate of chironomids increased by $\sim 50 \%$ and production (by area) increased 183\%, which had cascading impacts altering the nutrient stoichiometry of the entire ecosystem (Cross et al., 2003, 2005). Nutrient enrichment can, therefore, result in a dominance of small-bodied, fast-growing invertebrates, such as chironomids and snails (Elser et al., 1996; Frost et al., 2006; Singer \& Battin, 2007; Evans-White et al., 2009; Back \& King, 2013). Invertebrate assemblages with small-bodied individuals may be less energetically rewarding for fish and may alter fish communities (Schindler \& Eby, 1997; Vinson \& Baker, 2008; Shearer \& Hayes, 2019). Clearly, nutrient enrichment can alter macroinvertebrate communities via multiple mechanisms.

While the mechanisms and impacts of excessive nutrient enrichment of waterways have been well documented (Le Moal et al., 2019; Wurtsbaugh, Paerl \& Dodds, 2019; Mallin \& Cahoon, 2020), deriving nutrient criteria that are both protective of ecosystems and politically acceptable has proven challenging. Aside from management conflicts due to competing priorities, difficulties typically arise from uncertainty in relationships, discrepancies in criteria between different derivation methods, and a lack of suitable data (Huo et al., 2018; Phillips et al., 2019; Poikane et al., 2021). Often (but not always) setting instream nutrient criteria involves establishing relationships between biological metrics, such as those for macroinvertebrate assemblages, and nutrient concentrations, and then 
setting nutrient criteria that correspond to desired outcomes (Dodds, 2007; Evans-White, Haggard \& Scott, 2013; Huo et al., 2018; Poikane et al., 2019a). While the principle is similar, approaches and metrics for establishing nutrient criteria that correspond to desired macroinvertebrate outcomes have differed considerably between regions. For example, methods include: regression trees and two-dimensional KolmogorovSmirnov techniques in Wisconsin, USA (Wang, Robertson \& Garrison, 2007; Weigel \& Robertson, 2007); Threshold Indicator Taxa Analysis and quantile regression in Central Europe (Kail, Arle \& Jähnig, 2012); regressions and regression trees in Ohio, USA (Miltner, 2010); multivariate analysis in Ozark, USA (Justus et al., 2010); cluster analysis in New York State, USA (Smith, Bode \& Kleppel, 2007); nonparametric changepoint analysis in Florida, USA (King \& Richardson, 2003); regressions in England (Everall et al., 2019); and a compilation of methods based on their weight of evidence in New York State, USA (Smith \& Tran, 2010). There is no 'one size fits all' approach to deriving nutrient criteria, with methods often reflecting different data availability and the policy framework/ambitions they support. Regression approaches often try to derive nutrient criteria that correspond to desired biological targets, with the desired stringency (and certainty of outcome) dependent on the quantile used for the regression. While regression tree and changepoint methods seek nutrient criteria to prevent reaching ecological tipping points, rather than desired biological targets.

New Zealand (NZ), like many other parts of the world, faces eutrophication of its waterways, primarily from the intensification of agriculture. Fertilizer use in NZ has increased by 627\% between 1990 and 2015, with 70\% of rivers, by length, experiencing nutrient enrichment above natural levels, and many sites in declining condition (Ministry for the Environment \& Statistics New Zealand, 2020). Despite the declining water quality, the implementation and enforcement of suitable nutrient criteria have been the subject of intensive debate, with little resolution in recent national freshwater policy reforms (Joy \& Canning, 2020).

The development of suitable nutrient criteria for New Zealand's rivers and streams has, in part, been constrained by a lack of suitable data (Death et al., 2018; Canning, 2020). The monitoring of New Zealand's waterways is non-random, often reflecting points of interest and the objectives of environmental managers. As a result, many nutrient monitoring sites do not have biological monitoring and vice-versa, constraining the ability to form relationships between nutrients and biological responses. This limited dataset comprising only sites where both nutrients and biological monitoring occurs simultaneously may fail to encapsulate the range of possible responses, particularly if different river geomorphologies, land uses, or nutrient concentrations are under-represented (Canning, 2020). One way to circumvent the mismatch of data could be to use data predicted from national water quality models that cover all river reaches (Whitehead, 2018). While modelled data may fail to encapsulate localised nuances, advantages may include the smoothing of noisy data and full representation across the entire river network (Özkundakci et al., 2018). In-situ nutrient monitoring data is notoriously prone to high variability, with grab samples often influenced by hydrological patterns, geology, temporal variability in land uses/practices (e.g., time of fertiliser 
application), variability in biological uptake from diurnal processes and predator-prey cycling, and variation in other physicochemical conditions (e.g., dissolved oxygen and temperature) (e.g., Jordan, Correll \& Weller, 1997; Glibert et al., 2008; Aguilera, Marcé \& Sabater, 2012). Examining the differences in nutrient criteria derived from using measured data and from modelled data may build confidence in derived criteria if there is strong convergence or help elucidate whether further data collection is required.

In moves seeking to improve the health of the nation's freshwaters, the New Zealand Government developed the National Policy Statement for Freshwater Management (NPS-FM 2020). This new national policy prescribes three riverine macroinvertebrate indicators (termed 'attributes') of ecological health: (1) the Macroinvertebrate Community Index (MCI; Stark \& Maxted, 2007); (2) the quantitative variant of the MCI (QMCI; Stark \& Maxted, 2007); and (3) the average score per metric (ASPM) (Collier, 2008). The MCI and QMCI indicate the overall community's sensitivity to organic enrichment from weighted averages of species tolerance scores from presence-absence invertebrate surveys (MCI) or relative abundance surveys (QMCI). The ASPM is an overall indicator of community health and is the normalised average of the richness of Ephemeroptera, Plecoptera and Trichoptera taxa excluding Hydroptilidae (EPT), \% EPT and the macroinvertebrate community index (MCI) (Collier, 2008). The NPS-FM (2020) requires local authorities to improve the attributes for each river to at least the 'national bottom line' or better. The national bottom line targets are described by the NPS-FM (2020) as being broadly indicative of a moderate level of ecological integrity and organic pollution, with a mix of taxa sensitive and insensitive to organic pollution/nutrient enrichment. Local authorities must then also set nutrient criteria for dissolved inorganic nitrogen (DIN) and dissolved reactive phosphorus (DRP) at concentrations appropriate for achieving desired outcomes. Ideally, nutrient criteria would not be more stringent than required to support the desired ecological outcome (i.e., biology pass, yet nutrients fail prescribed criteria), or too weak to support the desired ecological outcome (i.e., biology fail, yet nutrients pass prescribed criteria).

The minimisation of mismatch between nutrients and biology ('minimisation-ofmismatch') approach, as described by the European Union's 'Best practice for establishing nutrient concentrations to support good ecological status' guidelines, provides an objective and robust method for deriving nutrient criteria (Phillips et al., 2018, 2019). The minimisation-of-mismatch approach seeks to identify nutrient criteria that are most likely to pass or fail when the ecological indicators also pass or fail respectively, is little affected by weak, nonlinear biology-nutrient regressions or data distribution. Minimisation-of-mismatch avoids the adoption of arbitrary percentiles that quantile regression approaches require; while changepoint analysis approaches are unable to benchmark nutrient criteria against pre-defined biological criteria-whereas minimisationof-mismatch can (Phillips et al., 2018, 2019). Poikane et al. (2019b) applied the method to derive nutrient criteria to support healthy European lakes and found the approach yielded similar nutrient criteria to the other methods examined. Broad agreement with other methods, tolerance of data structures, and the avoidance of arbitrary 
decision-making, would make the method attractive to decision-makers faced with politically contentious issues.

Here we aim to use the minimisation-of-mismatch approach to derive nutrient criteria for dissolved inorganic nitrogen (DIN) and dissolved reactive phosphorus (DRP) that support the achievement of the national bottom line targets for the three riverine macroinvertebrate attributes, as stipulated by New Zealand's NPS-FM 2020. Given that New Zealand's monitoring data is largely non-random (with some localised examples of randomised surveys), with nutrients measured at all biological monitoring sites, we also aim to compare the nutrient criteria derived when modelled nutrient data is used instead of measured data.

\section{MATERIALS \& METHODS}

\section{Macroinvertebrate and nutrient data}

Macroinvertebrate data used in this study was sourced from New Zealand's regional environmental monitoring network of rivers and streams (Ministry for the Environment \& Statistics New Zealand, 2019). Benthic macroinvertebrates were surveyed annually for five years during summer by regional authorities between 2012 and 2016, and the MCI, QMCI and ASPM scores calculated using a consistent taxonomic resolution by Clapcott et al. (2017). Macroinvertebrates were typically sampled in riffles using either kick nets or Surber samplers, with five to seven replicates, stored in either ethanol or formalin, and identified using common keys (e.g., Winterbourn, Gregson \& Dolphin, 1989; Moore, 1998). Surber sampling aimed to capture all invertebrates within a $0.1 \mathrm{~m}^{2}$ area to a depth of $\sim 10 \mathrm{~cm}$, whereas kick net sampling typically involved shuffling gravel for $\sim 1-2$ min until several hundred invertebrates are collected. While kick nets and Surber samplers may result in different invertebrate assemblages being collected, investigations by Stark (1993) suggest that differences in MCI and taxa richness are rarely significant. Surveys were collected from 1851 sites nationwide (Fig. 1).

DIN and DRP monitoring data was also sourced from New Zealand's regional environmental monitoring network of rivers and streams (Ministry for the Environment \& Statistics New Zealand, 2019). Between 2012 and 2016, grab samples testing DIN and DRP were collected monthly at 856 and 878 sites respectively, and summarised over the entire five-year period as a median for each site.

All modelled nutrient data was sourced from Whitehead (2018), and is also used in national environmental reporting (Ministry for the Environment \& Statistics New Zealand, 2019). Modelled nutrient data includes predictions of DIN (calculated as $\mathrm{NO}_{3}-\mathrm{N}+\mathrm{NH}_{4}$ $\mathrm{N})$ and DRP for every river reach across New Zealand's riverine network $(N=593,373$ reaches).

Two datasets were compiled for this analysis: (1) measured MCI, QMCI and ASPM scores at sites with DIN and DRP concentrations measured concurrently $\left(N_{\mathrm{MCI}}=450\right.$, $N_{\mathrm{QMCI}}=294, \& N_{\mathrm{ASPM}}=389$; Table 1); and (2) measured MCI, QMCI and ASPM scores at all invertebrate survey sites (regardless of whether nutrients were measured or not) with modelled DIN and DRP concentrations $\left(N_{\mathrm{MCI}}=1,729, N_{\mathrm{QMCI}}=1,450, \& N_{\mathrm{ASPM}}=1,729\right.$; Table 1). 


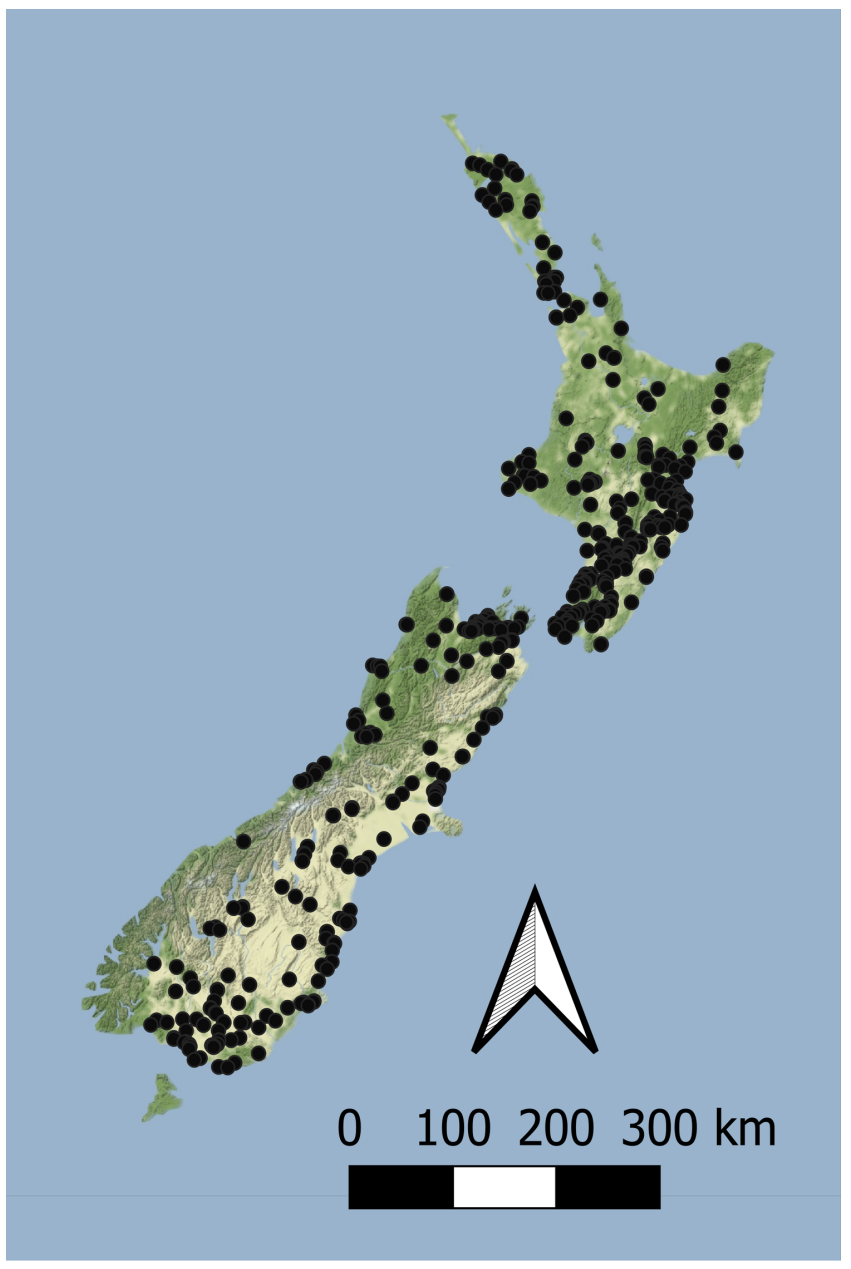

Figure 1 The location of sites with concurrent macroinvertebrate and nutrient monitoring across New Zealand. Sites are surveyed as part of New Zealand's state of environment monitoring between 2013 \& 2017 (Ministry for the Environment \& Statistics New Zealand, 2019). Macroinvertebrates are surveyed annually and nutrients are sampled monthly. $\quad$ Full-size $\boldsymbol{\oplus}$ DOI: 10.7717/peerj.11556/fig-1

To evaluate the efficacy of the nutrient models, using R 3.5.3 ( $R$ Development Core Team, 2019) linear regression analysis was used to examine the ability of the modelled nutrients to reflect the concentrations measured at sites in dataset (1). As a pre-cursor to the minimization-of-mismatch analysis, regression analysis was carried out between nutrient concentrations and the ecosystem health metrics for both datasets to ascertain the direction of change with nutrient enrichment, as recommended by Phillips et al. (2018).

\section{Minimization-of-mismatch analysis}

Using both datasets, minimization-of-mismatch analysis was used to estimate the DIN and DRP concentrations that corresponded to the national bottom line targets, as per the NPS-FM 2020, for each metric $(\mathrm{MCI}=90, \mathrm{QMCI}=4.5, \& \mathrm{ASPM}=0.3)$. The national bottom line targets used in the NPS-FM were established based on the advice on the advice of the Scientific and Technical Advisory Group informing the policy development framework, as informed by a review of macroinvertebrate indicators (Clapcott et al., 2017; 
Table 1 Summary statistics of raw invertebrate and nutrient data. The minimum, median, mean, maximum, 25th and 75th percentiles of MCI, QMCI, ASPM, measured DIN and DRP (ug/L), and modelled DIN and DRP across New Zealand's state of environment monitoring network data used in this analysis.

\begin{tabular}{llllllll} 
Dataset & Metric & \multicolumn{2}{l}{ Statistic } & & \\
\cline { 3 - 7 } Measured & & Min & 25th percentile & Median & Mean & 75th percentile & Max \\
\hline & MCI & 54.8 & 91.0 & 103.5 & 103.2 & 116.0 & 148.0 \\
& QMCI & 2.0 & 4.1 & 5.0 & 5.1 & 6.0 & 7.9 \\
& ASPM & 0.11 & 0.33 & 0.44 & 0.42 & 0.52 & 0.78 \\
& DIN & 1.0 & 51.5 & 241.0 & 567.3 & 670.0 & $1,0578.8$ \\
& DRP & 0.3 & 5.0 & 9.5 & 16.1 & 16.0 & 250.0 \\
Modelled & MCI & 34.8 & 88.4 & 104.1 & 103.0 & 118.0 & 161.3 \\
& QMCI & 2.0 & 4.3 & 5.6 & 5.7 & 6.6 & 106.2 \\
& ASPM & 0.07 & 0.28 & 0.43 & 0.41 & 0.54 & 0.83 \\
& DIN & 10.9 & 79.2 & 224.2 & 397.4 & 567.3 & $5,215.6$ \\
& DRP & 1.1 & 7.7 & 12.6 & 15.3 & 20.2 & 109.7 \\
\hline
\end{tabular}

Essential Freshwater Science \& Technical Advisory Group, 2019). Minimization-ofmismatch analysis estimates the nutrient concentration target that maximizes the probability of a site passing both the ecological metric target and the nutrient concentration target, while seeking to minimize the passing of the ecological target and failing on the nutrient target (vice-versa)-i.e., the mismatch in passing and failing grades is minimized (Phillips et al., 2018). The approach involves three steps: (1) plotting the percentage of water bodies that have a passing score for an ecosystem health metric but a failing nutrient status for different potential nutrient criteria values; (2) then plotting a similar, but inverse, plot with the percentage of water bodies where the ecosystem health metric fails but the nutrient criteria would pass; and then (3) identifying the intersect between the two plots, this indicates the nutrient concentration that minimizes the mismatch of passing and failing grades. For each relationship, this was repeated 1500 times with a random sub-sample using $75 \%$ of the total data (with replacement), with the median (mean, range and quantiles also calculated) representing the final nutrient criteria (Phillips et al., 2018, 2019; Poikane et al., 2019b).

\section{RESULTS}

Negative relationships were observed between all nutrient and ecosystem health metrics regressions, regardless of dataset (Figs. S1 \& S2; Table S1). Across the sites with measured nutrients, mismatch minimization analysis suggests, using the median (range), the best DIN criteria to achieve the national bottom lines for MCI, QMCI and ASPM were 1.07 (0.93-1.21) $\mathrm{mg} / \mathrm{L}, 0.62(0.46-0.77) \mathrm{mg} / \mathrm{L}$ and $1.12(1.00-1.29) \mathrm{mg} / \mathrm{L}$ respectively, while the DRP criteria were $0.028(0.025-0.030) \mathrm{mg} / \mathrm{L}, 0.018(0.015-0.020) \mathrm{mg} / \mathrm{L}$ and 0.028 (0.026-0.032) $\mathrm{mg} / \mathrm{L}$ respectively (Table 2; Fig. 2). While the nutrient criteria derived using all sites and using modelled nutrients suggests, using the median, the best DIN criteria to achieve the national bottom lines for MCI, QMCI and ASPM were $0.64(0.60-0.68) \mathrm{mg} / \mathrm{L}$, 

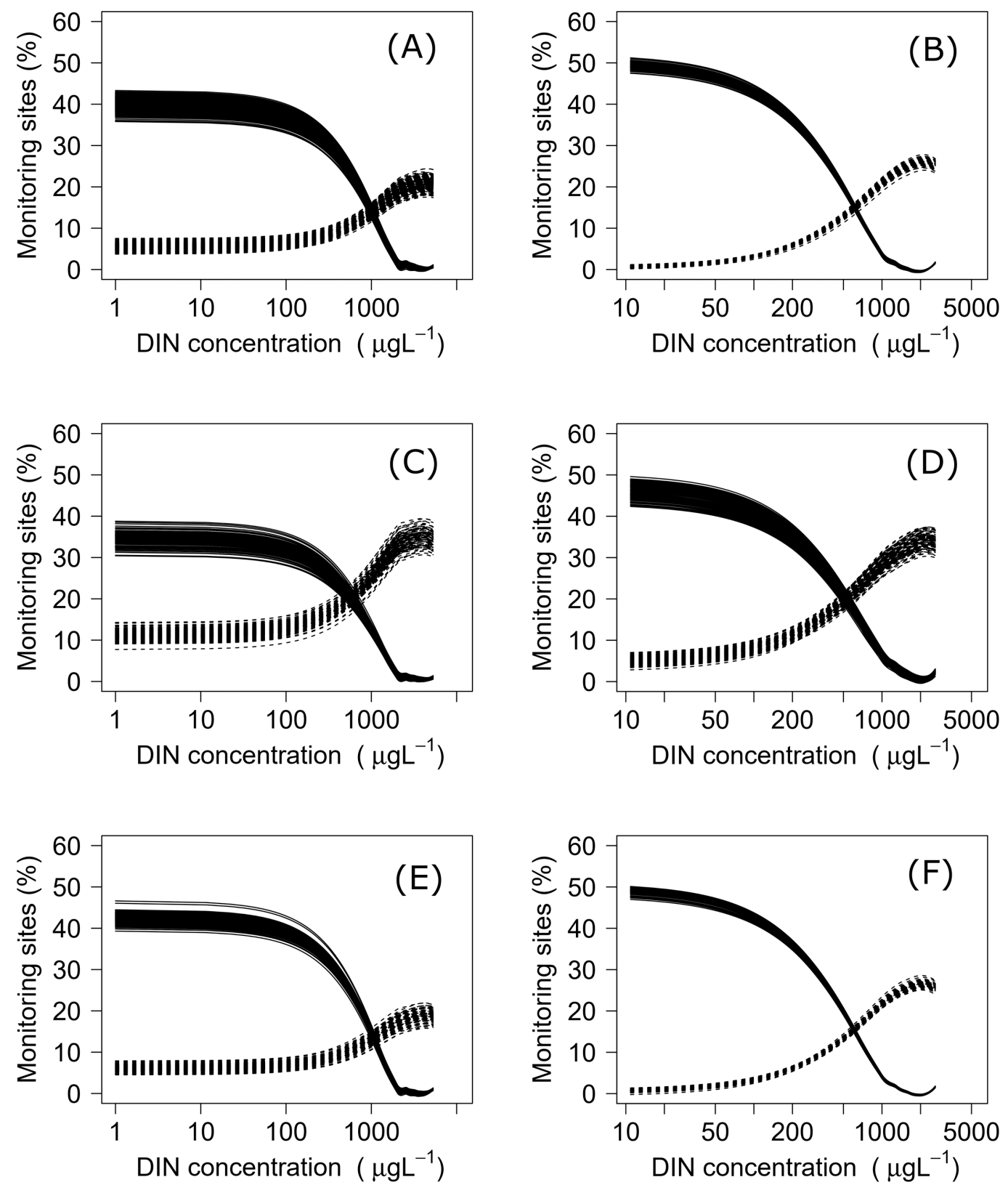

Figure 2 Minimisation-of-mismatch analysis to derive DIN criteria that support New Zealand's national macroinvertebrate targets. The proportion of water bodies that pass for ecosystem health but fail for nutrients (full line) and the proportion failing ecosystem health and passing DIN (dashed). A \& B represent MCI targets, C \& D represent QMCI targets, and E \& F represent ASPM targets, using measured and modelled nutrients respectively.

Full-size $\underset{0}{0}$ DOI: $10.7717 /$ peerj.11556/fig-2

$0.59(0.57-0.63) \mathrm{mg} / \mathrm{L}$ and $0.63(0.59-0.65) \mathrm{mg} / \mathrm{L}$ respectively, while the DRP criteria were $0.021(0.020-0.021) \mathrm{mg} / \mathrm{L}, 0.020(0.195-0.021) \mathrm{mg} / \mathrm{L}$ and $0.021(0.020-0.021) \mathrm{mg} / \mathrm{L}$ respectively (Table 2; Fig. 3). Modelled nutrients were highly correlated to measured nutrients at sites with concurrent macroinvertebrate monitoring (DIN: $\mathrm{R}^{2}=0.90$, $\mathrm{F}_{1,444}=4,146, P<0.001 ;$ DRP: $\left.\mathrm{R}^{2}=0.89, \mathrm{~F}_{1,445}=3,589, P<0.001\right)$. 
Table 2 Nutrient criteria to support New Zealand's national bottom line riverine macroinvertebrate targets. Statistics summarizing the DIN and DRP criteria (mg/L) produced using the minimization-of-mismatch method to support New Zealand's three macroinvertebrate national bottom lines set out in the NPS-FM 2020.

\begin{tabular}{|c|c|c|c|c|c|c|c|c|}
\hline \multirow[t]{2}{*}{ Nutrient dataset } & \multirow[t]{2}{*}{ Metric } & \multirow[t]{2}{*}{ Nutrient } & \multicolumn{6}{|c|}{ Statistic } \\
\hline & & & Min & Lower quartile & Median & Mean & Upper quartile & $\operatorname{Max}$ \\
\hline \multirow[t]{6}{*}{ Measured } & \multirow[t]{2}{*}{ MCI } & DIN & 0.93 & 1.04 & 1.07 & 1.07 & 1.10 & 1.21 \\
\hline & & DRP & 0.025 & 0.027 & 0.028 & 0.028 & 0.028 & 0.030 \\
\hline & \multirow[t]{2}{*}{ QMCI } & DIN & 0.46 & 0.57 & 0.63 & 0.62 & 0.67 & 0.77 \\
\hline & & DRP & 0.015 & 0.017 & 0.018 & 0.018 & 0.019 & 0.020 \\
\hline & \multirow[t]{2}{*}{ ASPM } & DIN & 1.01 & 1.09 & 1.12 & 1.13 & 1.16 & 1.29 \\
\hline & & DRP & 0.026 & 0.028 & 0.028 & 0.028 & 0.029 & 0.032 \\
\hline \multirow[t]{6}{*}{ Modelled } & \multirow[t]{2}{*}{ MCI } & DIN & 0.60 & 0.63 & 0.64 & 0.64 & 0.65 & 0.68 \\
\hline & & DRP & 0.020 & 0.021 & 0.021 & 0.021 & 0.021 & 0.021 \\
\hline & \multirow[t]{2}{*}{ QMCI } & DIN & 0.01 & 0.02 & 0.02 & 0.02 & 0.02 & 0.02 \\
\hline & & DRP & 0.019 & 0.020 & 0.020 & 0.020 & 0.020 & 0.021 \\
\hline & \multirow[t]{2}{*}{ ASPM } & DIN & 0.59 & 0.62 & 0.63 & 0.63 & 0.64 & 0.65 \\
\hline & & DRP & 0.020 & 0.020 & 0.021 & 0.021 & 0.021 & 0.021 \\
\hline
\end{tabular}

\section{DISCUSSION}

When using measured nutrient data, the nutrient criteria derived to support achieving the national bottom line targets for QMCI were more stringent than those for MCI and ASPM. Although the MCI and QMCI are often correlated and similar criteria would be anticipated (Wright-Stow \& Winterbourn, 2003), the QMCI may be more sensitive to change as it accounts for changes in species abundance, whereas MCI and ASPM scores only change when a species becomes present or absent entirely. Interestingly, when the larger macroinvertebrate dataset was used with modelled nutrients, the nutrient criteria across all three metrics converged very closely to give a DIN criteria at $\sim 0.6 \mathrm{mg} / \mathrm{L}$ and DRP criteria at $\sim 0.02 \mathrm{mg} / \mathrm{L}-$ similar to those derived for the QMCI using measured nutrients. The criteria derived using the measured nutrient dataset were, however, more variable than those derived using modelled nutrients. By using modelled nutrients, a larger invertebrate metric dataset was permissible, potentially allowing for greater refinement of nutrient criteria and mitigating against the uncertainty arising from the presence-absence based indicators.

The divergence in criteria between those produced with the measured versus modelled nutrient concentrations, may also arise from uncertainty in estimating high nutrient concentrations. In-situ nutrient concentrations are highly variable, particularly influenced by season and rainfall, with the range of variability typically increasing with increased nutrient concentrations (e.g., Jordan, Correll \& Weller, 1997; Glibert et al., 2008; Aguilera, Marcé \& Sabater, 2012). The modelled concentrations were well correlated to measured concentrations, as observed in Fig. 4, the modelled concentrations systematically under-estimate high concentrations and over-estimate low concentration. This may be attributed to having fewer residuals at the extremities to anchor the model, leading to 

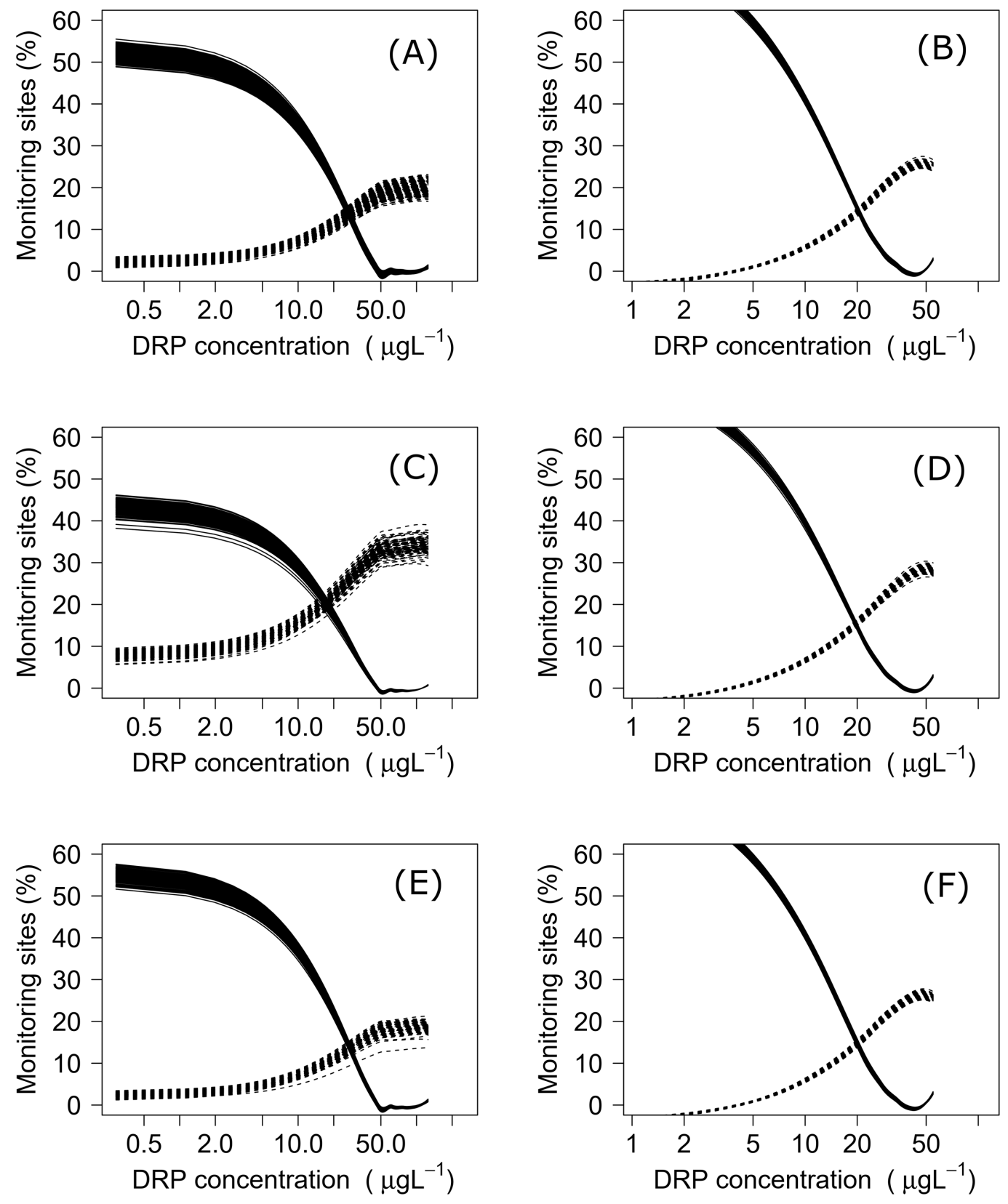

Figure 3 Minimisation-of-mismatch analysis to derive DRP criteria that support New Zealand's national macroinvertebrate targets. The proportion of water bodies that pass for ecosystem health but fail for nutrients (full line) and the proportion failing ecosystem health and passing DRP (dashed). A \& B represent MCI targets, C \& D represent QMCI targets, and E \& F represent ASPM targets, using measured and modelled nutrients respectively. Full-size $\underset{0}{0}$ DOI: 10.7717 /peerj.11556/fig-3

greater uncertainty when predicting high concentrations. Incorporating more data from new sites with very high nutrient concentrations may help increase the confidence of derived nutrient criteria; however, this was not available at the time of analysis, and finding numerous highly enriched sites may not be possible if they do not exist. The level of uncertainty accepted for environmental management will inevitably depend on the values 

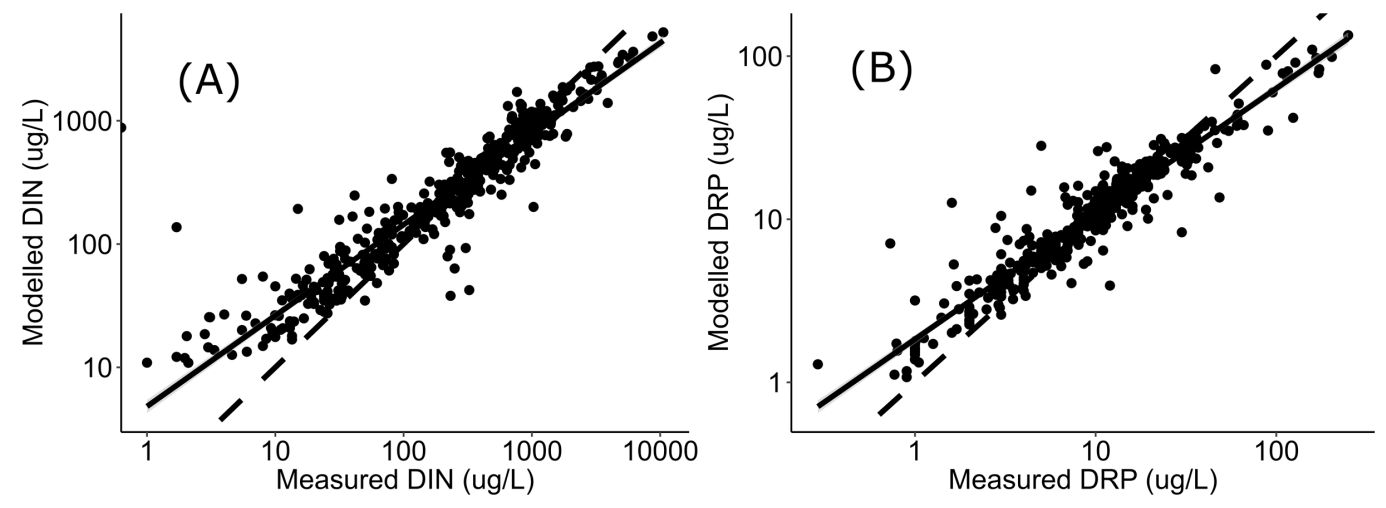

Figure 4 Regressions between measured and modelled nutrient concentrations. Regressions (log-log transformed) between (A) modelled DIN and measured DIN, and (B) modelled DRP and measured DRP at all sites in Data S1 and Fig. 1. Data sourced from New Zealand's state of environment monitoring between 2013 \& 2017 (Ministry for the Environment, Statistics New Zealand, Environment M for the Zealand SN, 2019). Full-size $\operatorname{i\in }$ DOI: 10.7717/peerj.11556/fig-4

guiding the management and policy framework they sit within. If a precautionary approach to environmental management of national bottom lines is desired, then this analysis suggests the DIN and DRP criteria would need to be $\sim 0.6 \mathrm{mg} / \mathrm{L}$ and $\sim 0.02 \mathrm{mg} / \mathrm{L}$ respectively, or better, particularly given that both measured and modelled nutrient datasets both yielded similarly stringent criteria for supporting the QMCI targets. The nitrogen criteria derived here also fit within the range recommended by Camargo \& Alonso (2006), who conducted a global review of inorganic nitrogen pollution in rivers and suggested levels should be less than $0.5-1 \mathrm{mg} / \mathrm{L}$ to prevent eutrophication and protect against toxicity.

In addition to the differences arising from sample size and whether measured or modelled nutrients are used, variability in nutrient criteria can also arise from unaccounted external environmental influences and normative decisions made in the derivation process. While nutrient enrichment is highly influential in driving New Zealand's macroinvertebrate assemblages, other factors such as sedimentation, riparian habitat, pesticides, water hardness, $\mathrm{pH}$, temperature, flow and substrate composition are also influential (Wagenhoff, Townsend \& Matthaei, 2012; Burdon, McIntosh \& Harding, 2013; Death et al., 2015; Matthaei \& Piggott, 2019; Salis et al., 2019). In consequence, these factors may be limiting or altering the restoration of macroinvertebrate communities, and failure to address other stressors may result in the desired ecological outcomes not being realized. While uncertainty can also arise from nutrient grab samples, as nutrients can fluctuate diurnally, and seasonally with rainfall patterns and agricultural practices (Withers \& Jarvie, 2008; Causse et al., 2015). Therefore, an assessment period too short may be highly influenced by temporal variability, while variability in very long assessment periods may arise from an improving or declining trend - consequently, deciding the period of assessment to ascertain the state and assess against criteria presents a balance. In this study, grade assessment was made against data summarised at a site over a five-year period, in line with New Zealand's NPS-FM (2020) and State of Environment reporting (Ministry for the Environment \& Statistics New Zealand, 2019). It is also encouraging that 
the ranges, particularly the interquartile ranges, of nutrient criteria produced for each metric were generally low, suggesting the criteria would be broadly applicable.

Other published nutrient criteria derived for New Zealand rivers include those from the Australia and New Zealand Guidelines (ANZG), those derived by models to support periphyton objectives (Biggs, 2000; Biggs \& Kilroy, 2000; Snelder, Moore \& Kilroy, 2019), and those derived for macroinvertebrates within the Manawatu-Whanganui region (Wagenhoff et al., 2017a, 2017b; Canning \& Death, 2021). The nutrient criteria derived here are considerably more lenient than the ANZG criteria. The ANZG criteria for NZ rivers are derived from the arbitrary percentile of nutrient concentrations predicted to occur in reference conditions for different river typologies. The ANZG criteria are not intended to support a desired ecological state but are to trigger the indication of nutrient concentrations significantly greater than natural state. The nutrient criteria required to achieve the national bottom line targets for periphyton were generally more stringent than those derived here to support the macroinvertebrate metrics, though they vary substantially depending on river geology and hydrology. While explorations using data from the Manawatu-Whanganui region suggest the impact of nutrients on various macroinvertebrate community metrics, macroinvertebrate assemblage turnover, and metrics of food web function, ceased at nitrogen concentrations in excess of $0.5 \mathrm{mg} / \mathrm{L}$ - similar, but slightly more stringent than those derived here (Wagenhoff et al., 2017a, 2017b; Canning \& Death, 2021). Adopting any of these alternative nutrient criteria would likely provide sufficient nutrient protection to support achieving any of the three macroinvertebrate national bottom line target states, though the relative stringency of alternative nutrient criteria would vary with hydrology, geology and values being managed.

While other jurisdictions have developed nutrient criteria for separate eco-regions (e.g., Zhou \& Zheng, 2008; Chambers et al., 2012; USEPA, 2019), we consider that New Zealand likely falls within its own eco-region and did not consider it necessary to develop eco-regionalized nutrient criteria. Given New Zealand's small size, mountainous geology, short-run rivers and highly variable flood frequency, previous studies have shown that New Zealand rivers share a common core assemblage of macroinvertebrates that are ecologically flexible and have poorly synchronised life histories (Winterbourn, Rounick \& Cowie, 1981; Quinn \& Hickey, 1990; Thompson \& Townsend, 2000). Previous explorations using machine learning have also shown that nutrient concentrations and land use are, by considerable margins, the most influential variables predicting the three metrics, despite an array of other potential predictors covering hydrology, geology and climate (Clapcott et al., 2012, 2017; Canning, 2020). A New Zealand freshwater macroinvertebrate eco-region is also considerably smaller than those in other regions. For example, the eco-regions for USA rivers are, on average, 13 times larger than New Zealand (USEPA, 2019), while those described in China are six times larger (Zhou \& Zheng, 2008). Splicing New Zealand into smaller eco-regions when deriving nutrient criteria would mean substantially fewer sites. These sites may fail to encapsulate the range of possible responses, particularly if different river geomorphologies, land uses, or nutrient concentrations are under-represented and yield more uncertain criteria than that from a larger, nationally derived dataset (Canning, 2020). Finally, the mismatch rates were low, 
ranging between $10-15 \%$ (Figs. 2 \& 3), and ranges of derived criteria generally narrow, suggesting that the nutrient criteria produced correspond well to the desired biological outcomes for most rivers.

While the nutrient criteria derived here will be useful for supporting the achievement of national macroinvertebrate targets, New Zealand's National Policy Statement for Freshwater Management (2020) also requires regional authorities to set nutrient criteria to support achievement of other ecological and social targets, which can vary between rivers. Setting nutrient criteria is a multi-disciplinary challenge, involving the political judgement of the implications arising from multiple potential criteria designed to support different ecological, social, cultural, and economic values and objectives. For example, more stringent criteria may be required to achieve other ecological objectives, such as those for algal biomass and dissolved oxygen. Social values affected by nutrient criteria may include recreation (e.g., sports fishing, swimming and boating), identity (i.e., how society views, and connects with, the environment as part of their identity), or human health. For example, a recent meta-analysis observed a statistically significant positive association between nitrate exposure and risk of colorectal cancer (Temkin et al., 2019). Cultural values, such as traditional practices (e.g., indigenous food collection) and New Zealand's 'Te Mana o Te Wai', may also affect nutrient criteria. Te Mana o Te Wai is a Māori (New Zealand Indigenous) concept that is now embedded within, and mandated by, New Zealand's NPS-FM (2020), refers to the continued protection and restoration of water and sets the priority by which water use must occur (Te Aho, 2018). Te Mana o Te Wai mandates that the health and wellbeing of waterways must be prioritized first, followed by the needs of people (e.g., drinking water), and then the social, cultural and economic needs (Te Aho, 2018; Essential Freshwater Kahui Wai Maori Advisory Group, 2019). While economic values affected by nutrient criteria may include the extent to which productive land can be farmed intensively or the extent to which New Zealand's 'clean and green' branding is improved, maintained, or eroded (Tait et al., 2013; Foote, Joy \& Death, 2015; McDowell et al., 2020b). The integration of these values influenced by nutrient criteria, the levels of precaution they require, and the implications within the legislative framework, are beyond the scope of this paper but are clearly important considerations.

\section{CONCLUSIONS}

New Zealand's waterways have been experiencing considerable and widespread nutrient enrichment. We use the minimization-of-mismatch analysis to derive nutrient criteria that could support achievement of national aspirations for three macroinvertebrate indicators of riverine health. This analysis suggests that median DIN concentrations of $\sim 0.6 \mathrm{mg} / \mathrm{L}$ and median DRP concentrations of $\sim 0.02 \mathrm{mg} / \mathrm{L}$ would be suitable for supporting macroinvertebrate targets.

\section{ADDITIONAL INFORMATION AND DECLARATIONS}

\section{Funding}

The authors received no funding for this work. 


\section{Competing Interests}

All authors were members of the Essential Freshwater Scientific and Technical Advisory Group. Members advised the New Zealand Government's Essential Freshwater programme that developed the National Policy Statement for Freshwater Management (2020), and were acting in a voluntary and independent capacity.

\section{Author Contributions}

- Adam D. Canning conceived and designed the experiments, performed the experiments, analyzed the data, prepared figures and/or tables, authored or reviewed drafts of the paper, and approved the final draft.

- Michael K. Joy conceived and designed the experiments, authored or reviewed drafts of the paper, and approved the final draft.

- Russell G. Death conceived and designed the experiments, authored or reviewed drafts of the paper, and approved the final draft.

\section{Data Availability}

The following information was supplied regarding data availability:

Data are available in the Supplemental Files.

\section{Supplemental Information}

Supplemental information for this article can be found online at http://dx.doi.org/10.7717/ peerj.11556\#supplemental-information.

\section{REFERENCES}

Aguilera R, Marcé R, Sabater S. 2012. Linking in-stream nutrient flux to land use and inter-annual hydrological variability at the watershed scale. Science of the Total Environment 440(1/2):72-81 DOI 10.1016/j.scitotenv.2012.08.030.

Te Aho L. 2018. Te Mana o te Wai: an indigenous perspective on rivers and river management. River Research and Applications 35(10):1615-1621 DOI 10.1002/rra.3365.

Back JA, King RS. 2013. Sex and size matter: ontogenetic patterns of nutrient content of aquatic insects. Freshwater Science 32(3):837-848 DOI 10.1899/12-181.1.

Benstead JP, Rosemond AD, Cross WF, Wallace JB, Eggert SL, Suberkropp K, Gulis V, Greenwood JL, Tant CJ. 2009. Nutrient enrichment alters storage and fluxes of detritus in a headwater stream ecosystem. Ecology 90(9):2556-2566 DOI 10.1890/08-0862.1.

Biggs BJ. 2000. New Zealand periphyton guideline: detecting, monitoring and managing enrichment of streams. Ministry for the Environment.

Biggs BJF, Kilroy C. 2000. Stream periphyton monitoring manual. Christchurch, New Zealand: National Institute of Water and Atmospheric Research. Available at https://environment.govt.nz/ publications/new-zealand-periphyton-guideline-detecting-monitoring-and-managingenrichment-of-streams/.

Burdon FJ, McIntosh AR, Harding JS. 2013. Habitat loss drives threshold response of benthic invertebrate communities to deposited sediment in agricultural streams. Ecological Applications 23(5):1036-1047 DOI 10.1890/12-1190.1. 
Camargo J, Alonso Á. 2006. Ecological and toxicological effects of inorganic nitrogen pollution in aquatic ecosystems: a global assessment. Environment International 32(6):831-849 DOI 10.1016/j.envint.2006.05.002.

Canning A. 2020. Nutrients in New Zealand rivers and streams: an exploration and derivation of national nutrient criteria. Wellington, New Zealand: Essential Freshwater Science and Technical Advisory Group DOI 10.6084/m9.figshare.12116460.

Canning A, Death R. 2021. The influence of nutrient enrichment on riverine food web function and stability. Ecology and Evolution 11(2):942-954 DOI 10.1002/ece3.7107.

Causse J, BaurèS E, Mery Y, Jung A-V, Thomas O. 2015. Variability of $\mathrm{N}$ export in water: a review. Critical Reviews in Environmental Science and Technology 45(20):2245-2281 DOI 10.1080/10643389.2015.1010432.

Chambers PA, McGoldrick DJ, Brua RB, Vis C, Culp JM, Benoy GA. 2012. Development of environmental thresholds for nitrogen and phosphorus in streams. Journal of Environmental Quality 41(1):7-20 DOI 10.2134/jeq2010.0273.

Clapcott JE, Collier KJ, Death RG, Goodwin EO, Harding JS, Kelly D, Leathwick JR, Young RG. 2012. Quantifying relationships between land-use gradients and structural and functional indicators of stream ecological integrity. Freshwater Biology 57(1):74-90

DOI 10.1111/j.1365-2427.2011.02696.x.

Clapcott J, Wagenhoff A, Neale M, Storey R, Smith B, Death R, Harding J, Matthaei C, Quinn J, Collier K, Atalah J, Goodwin E, Rabel H, Mackman J, Young R. 2017. Macroinvertebrate metrics for the National Policy Statement for Freshwater Management. Nelson, New Zealand, New Zealand. Available at https://environment.govt.nz/publications/macroinvertebrate-metricsfor-the-national-policy-statement-for-freshwater-management/.

Collier K. 2008. Average score per metric: an alternative metric aggregation method for assessing wadeable stream health. New Zealand Journal of Marine and Freshwater Research 42(4):367-378 DOI 10.1080/00288330809509965.

Cross WF, Benstead JP, Rosemond AD, Bruce Wallace J. 2003. Consumer-resource stoichiometry in detritus-based streams. Ecology Letters 6(8):721-732 DOI 10.1046/j.1461-0248.2003.00481.x.

Cross WF, Johnson BR, Wallace JB, Rosemond AD. 2005. Contrasting response of stream detritivores to long-term nutrient enrichment. Limnology and Oceanography 50(6):1730-1739 DOI 10.4319/lo.2005.50.6.1730.

Cross WF, Wallace JB, Rosemond AD, Eggert SL. 2006. Whole-system nutrient enrichment increases secondary production in a detritus-based ecosystem. Ecology 87(6):1556-1565 DOI 10.1890/0012-9658(2006)87[1556:WNEISP]2.0.CO;2.

Death RG, Canning A, Magierowski R, Tonkin J. 2018. Why aren't we managing water quality to protect ecological health?. Palmerston North, New Zealand: Fertilizer and Lime Research Centre, Massey University.

Death RG, Death F, Stubbington R, Joy MK, van den Belt M. 2015. How good are Bayesian belief networks for environmental management? A test with data from an agricultural river catchment. Freshwater Biology 60(11):2297-2309 DOI 10.1111/fwb.12655.

Demi LM, Benstead JP, Rosemond AD, Maerz JC. 2018. Litter P content drives consumer production in detritus-based streams spanning an experimental N: P gradient. Ecology 99(2):347-359 DOI 10.1002/ecy.2118.

Dodds W. 2007. Trophic state, eutrophication and nutrient criteria in streams. Trends in Ecology \& Evolution 22(12):669-676 DOI 10.1016/j.tree.2007.07.010. 
Dodds W, Smith V. 2016. Nitrogen, phosphorus, and eutrophication in streams. Inland Waters 6(2):155-164 DOI 10.5268/IW-6.2.909.

Elser JJ, Dobberfuhl DR, MacKay NA, Schampel JH. 1996. Organism size, life history, and N: P stoichiometry: toward a unified view of cellular and ecosystem processes. BioScience 46(9):674-684 DOI 10.2307/1312897.

Elser JJ, Sterner RW, Gorokhova E, Fagan WF, Markow TA, Cotner JB, Harrison JF, Hobbie SE, Odell GM, Weider LW. 2000. Biological stoichiometry from genes to ecosystems. Ecology Letters 3(6):540-550 DOI 10.1046/j.1461-0248.2000.00185.x.

Essential Freshwater Kahui Wai Maori Advisory Group. 2019. Te Mana o te Wai: Kahui Wai Maori Report to Hon Minister David Parker. Wellington, New Zealand. Available at https:// environment.govt.nz/publications/te-mana-o-te-wai-the-health-of-our-wai-the-health-of-ournation-kahui-wai-maori-report-to-hon-minister-david-parker/.

Essential Freshwater Science and Technical Advisory Group. 2019. Freshwater science and technical advisory group supplementary report to the Minister for the Environment. Wellington, New Zealand. Available at https://environment.govt.nz/publications/freshwater-science-andtechnical-advisory-group-report-to-the-minister-for-the-environment/.

Evans-White MA, Dodds WK, Huggins DG, Baker DS. 2009. Thresholds in macroinvertebrate biodiversity and stoichiometry across water-quality gradients in Central Plains (USA) streams. Journal of the North American Benthological Society 28(4):855-868 DOI 10.1899/08-113.1.

Evans-White MA, Haggard BE, Scott JT. 2013. A review of stream nutrient criteria development in the United States. Journal of Environmental Quality 42(4):1002-1014

DOI 10.2134/jeq2012.0491.

Everall NC, Johnson MF, Wood P, Paisley MF, Trigg DJ, Farmer A. 2019. Macroinvertebrate community structure as an indicator of phosphorus enrichment in rivers. Ecological Indicators 107:105619 DOI 10.1016/j.ecolind.2019.105619.

Ferreira V, Castagneyrol B, Koricheva J, Gulis V, Chauvet E, Graça MASS. 2015. A meta-analysis of the effects of nutrient enrichment on litter decomposition in streams. Biological Reviews 90(3):669-688 DOI 10.1111/brv.12125.

Foote KJ, Joy MK, Death RG. 2015. New Zealand dairy farming: milking our environment for all it's worth. Environmental Management 56(3):709-720 DOI 10.1007/s00267-015-0517-x.

Frainer A, Jabiol J, Gessner MO, Bruder A, Chauvet E, McKie BG. 2016. Stoichiometric imbalances between detritus and detritivores are related to shifts in ecosystem functioning. Oikos 125(6):861-871 DOI 10.1111/oik.02687.

Frost PC, Benstead JP, Cross WF, Hillebrand H, Larson JH, Xenopoulos MA, Yoshida T. 2006. Threshold elemental ratios of carbon and phosphorus in aquatic consumers. Ecology Letters 9(7):774-779 DOI 10.1111/j.1461-0248.2006.00919.x.

Gillooly JF, Allen AP, Brown JH, Elser JJ, del Rio CM, Savage VM, West GB, Woodruff WH, Woods HA. 2005. The metabolic basis of whole-organism RNA and phosphorus content. Proceedings of the National Academy of Sciences of the United States of America 102(33):11923-11927 DOI 10.1073/pnas.0504756102.

Glibert PM, Kelly V, Alexander J, Codispoti LA, Boicourt WC, Trice TM, Michael B. 2008. In situ nutrient monitoring: a tool for capturing nutrient variability and the antecedent conditions that support algal blooms. Harmful Algae 8(1):175-181 DOI 10.1016/j.hal.2008.08.013.

Goedkoop W, Demandt M, Ahlgren G. 2007. Interactions between food quantity and quality (long-chain polyunsaturated fatty acid concentrations) effects on growth and development of Chironomus riparius. Canadian Journal of Fisheries and Aquatic Sciences 64(3):425-436 DOI 10.1139/f07-016. 
Guo F, Kainz MJ, Valdez D, Sheldon F, Bunn SE. 2016. The effect of light and nutrients on algal food quality and their consequent effect on grazer growth in subtropical streams. Freshwater Science 35(4):1202-1212 DOI 10.1086/688092.

Hessen DO, Elser JJ, Sterner RW, Urabe J. 2013. Ecological stoichiometry: an elementary approach using basic principles. Limnology and Oceanography 58(6):2219-2236 DOI 10.4319/lo.2013.58.6.2219.

Hessen DO, Ventura M, Elser JJ. 2008. Do phosphorus requirements for RNA limit genome size in crustacean zooplankton? Genome 51(9):685-691 DOI 10.1139/G08-053.

Huo S, Ma C, Xi B, Zhang Y, Wu F, Liu H. 2018. Development of methods for establishing nutrient criteria in lakes and reservoirs: a review. Journal of Environmental Sciences 67(1):54-66 DOI 10.1016/j.jes.2017.07.013.

Jordan TE, Correll DL, Weller DE. 1997. Relating nutrient discharges from watersheds to land use and streamflow variability. Water Resources Research 33(11):2579-2590 DOI 10.1029/97WR02005.

Joy MK, Canning AD. 2020. Shifting baselines and political expediency in New Zealand's freshwater management. Marine and Freshwater Research 72(4):456-461.

Justus BG, Petersen JC, Femmer SR, Davis JV, Wallace JE. 2010. A comparison of algal, macroinvertebrate, and fish assemblage indices for assessing low-level nutrient enrichment in wadeable Ozark streams. Ecological Indicators 10(3):627-638 DOI 10.1016/j.ecolind.2009.10.007.

Kahiluoto H, Kuisma M, Kuokkanen A, Mikkilä M, Linnanen L. 2014. Taking planetary nutrient boundaries seriously: can we feed the people? Global Food Security 3(1):16-21 DOI 10.1016/j.gfs.2013.11.002.

Kail J, Arle J, Jähnig SC. 2012. Limiting factors and thresholds for macroinvertebrate assemblages in European rivers: empirical evidence from three datasets on water quality, catchment urbanization, and river restoration. Ecological Indicators 18:63-72 DOI 10.1016/j.ecolind.2011.09.038.

Kiffney PM, Richardson JS. 2001. Interactions among nutrients, periphyton, and invertebrate and vertebrate (Ascaphus truei) grazers in experimental channels. Copeia 2001(2):422-429 DOI 10.1643/0045-8511(2001)001[0422:IANPAI]2.0.CO;2.

King RS, Richardson CJ. 2003. Integrating bioassessment and ecological risk assessment: an approach to developing numerical water-quality criteria. Environmental Management 31(6):795-809 DOI 10.1007/s00267-002-0036-4.

Le Moal M, Gascuel-Odoux C, Ménesguen A, Souchon Y, Étrillard C, Levain A, Moatar F, Pannard A, Souchu P, Lefebvre A, Pinay G. 2019. Eutrophication: a new wine in an old bottle? Science of the Total Environment 651(6771):1-11 DOI 10.1016/j.scitotenv.2018.09.139.

Mallin MA, Cahoon LB. 2020. The hidden impacts of phosphorus pollution to streams and rivers. BioScience 70(4):315-329 DOI 10.1093/biosci/biaa001.

Matthaei CD, Piggott JJ. 2019. Chapter 13-multiple stressors in Australia and New Zealand. In: Sabater S, Elosegi A, Ludwig RBTMS, eds. Key Stressors and Interactions. Amsterdam: Elsevier, 221-233.

McDowell RW, Noble A, Pletnyakov P, Haggard BE, Mosley LM. 2020a. Global mapping of freshwater nutrient enrichment and periphyton growth potential. Scientific Reports 10(1):3568 DOI 10.1038/s41598-020-60279-w.

McDowell RW, Pletnyakov P, Lim A, Salmon G. 2020b. Implications of water quality policy on land use: a case study of the approach in New Zealand. Marine and Freshwater Research 72:451-455. 
Miltner RJ. 2010. A method and rationale for deriving nutrient criteria for small rivers and streams in Ohio. Environmental Management 45(4):842-855 DOI 10.1007/s00267-010-9439-9.

Ministry for the Environment \& Statistics New Zealand. 2019. New Zealand's Environmental Reporting Series: Reference Ministry for the Environment, Statistics New Zealand, Environment M for the, Zealand SN (2019) is incomplete. Please provide the relevant missing information: website.Environment Aotearoa 2015. Wellington, New Zealand. Available at https://environment.govt.nz/publications/environment-aotearoa-2019/.

Ministry for the Environment \& Statistics New Zealand. 2020. New Zealand's environmental reporting series: our freshwater 2020. Wellington, New Zealand. Available at https:/environment.govt.nz/publications/our-freshwater-2020/.

Moore SC. 1998. A photographic guide to freshwater invertebrates of Taranaki's Rivers and Streams. Taranaki Regional Council. Available at https://www.trc.govt.nz/assets/Documents/ Research-reviews/Freshwater/Photographic-Guide-sm.pdf.

Mueller-Navarra D. 1995. Evidence that a highly unsaturated fatty acid limits Daphnia growth in nature. Archiv fur Hydrobiologie 132(3):297-307 DOI 10.1127/archiv-hydrobiol/132/1995/297.

Nash KL, Cvitanovic C, Fulton EA, Halpern BS, Milner-Gulland EJ, Watson RA, Blanchard JL. 2017. Planetary boundaries for a blue planet. Nature Ecology \& Evolution 1(11):1625-1634 DOI 10.1038/s41559-017-0319-z.

Özkundakci D, Wallace P, Jones HFE, Hunt S, Giles H. 2018. Building a reliable evidence base: legal challenges in environmental decision-making call for a more rigorous adoption of best practices in environmental modelling. Environmental Science \& Policy 88(21):52-62 DOI 10.1016/j.envsci.2018.06.018.

Persson J, Fink P, Goto A, Hood JM, Jonas J, Kato S. 2010. To be or not to be what you eat: regulation of stoichiometric homeostasis among autotrophs and heterotrophs. Oikos 119(5):741-751 DOI 10.1111/j.1600-0706.2009.18545.x.

Phillips G, Kelly M, Teixeira H, Salas F, Free G, Leujak W, Solheim AL, Várbíró G, Poikane S. 2018. Best practice for establishing nutrient concentrations to support good ecological status. In: Technical Report EUR 29329 EN. Publications Office of the European Union Luxembourg. 142.

Phillips G, Teixeira H, Poikane S, Salas Herrero F, Kelly MG. 2019. Establishing nutrient thresholds in the face of uncertainty and multiple stressors: a comparison of approaches using simulated datasets. Science of the Total Environment 684(1):425-433

DOI 10.1016/j.scitotenv.2019.05.343.

Poikane S, Kelly MG, Salas Herrero F, Pitt J-A, Jarvie HP, Claussen U, Leujak W, Lyche Solheim A, Teixeira H, Phillips G. 2019a. Nutrient criteria for surface waters under the European Water Framework Directive: current state-of-the-art, challenges and future outlook. Science of the Total Environment 695(1-3):133888 DOI 10.1016/j.scitotenv.2019.133888.

Poikane S, Phillips G, Birk S, Free G, Kelly MG, Willby NJ. 2019b. Deriving nutrient criteria to support $\bigotimes$ good $\bigotimes$ ecological status in European lakes: an empirically based approach to linking ecology and management. Science of the Total Environment 650(1):2074-2084 DOI 10.1016/j.scitotenv.2018.09.350.

Poikane S, Várbíró G, Kelly MG, Birk S, Phillips G. 2021. Estimating river nutrient concentrations consistent with good ecological condition: more stringent nutrient thresholds needed. Ecological Indicators 121(2):107017 DOI 10.1016/j.ecolind.2020.107017.

Quinn JM, Hickey CW. 1990. Characterisation and classification of benthic invertebrate communities in 88 New Zealand rivers in relation to environmental factors. New Zealand Journal of Marine and Freshwater Research 24(3):387-409

DOI 10.1080/00288330.1990.9516432. 
R Development Core Team. 2019. $R$ : a language and environment for statistical computing. Vienna: The R Foundation for Statistical Computing. Available at http://www.R-project.org/.

Salis RK, Bruder A, Piggott JJ, Summerfield TC, Matthaei CD. 2019. Multiple-stressor effects of dicyandiamide (DCD) and agricultural stressors on trait-based responses of stream benthic algal communities. Science of the Total Environment 693:133305

DOI 10.1016/j.scitotenv.2019.07.111.

Schindler DE, Eby LA. 1997. Stoichiometry of fishes and their prey: implications for nutrient recycling. Ecology 78(6):1816-1831 DOI 10.1890/0012-9658(1997)078[1816:SOFATP]2.0.CO;2.

Shearer KA, Hayes J. 2019. Assessing aquatic invertebrate prey indices for fish: trout. Prepared for Ministry for the Environment. Nelson, New Zealand.

Singer GA, Battin TJ. 2007. Anthropogenic subsidies alter stream consumer-resource stoichiometry, biodiversity, and food chains. Ecological Applications 17(2):376-389 DOI 10.1890/06-0229.

Smith AJ, Bode RW, Kleppel GS. 2007. A nutrient biotic index (NBI) for use with benthic macroinvertebrate communities. Ecological Indicators 7(2):371-386 DOI 10.1016/j.ecolind.2006.03.001.

Smith AJ, Tran CP. 2010. A weight-of-evidence approach to define nutrient criteria protective of aquatic life in large rivers. Journal of the North American Benthological Society 29(3):875-891 DOI 10.1899/09-076.1.

Snelder TH, Moore C, Kilroy C. 2019. Nutrient concentration targets to achieve periphyton biomass objectives incorporating uncertainties. JAWRA Journal of the American Water Resources Association 55(6):1443-1463 DOI 10.1111/1752-1688.12794.

Stark JD. 1993. Performance of the Macroinvertebrate Community Index: effects of sampling method, sample replication, water depth, current velocity, and substratum on index values. New Zealand Journal of Marine and Freshwater Research 27(4):463-478 DOI 10.1080/00288330.1993.9516588.

Stark JD, Maxted JR. 2007. A user guide for the macroinvertebrate community index. Nelson, New Zealand.

Tait DP, Saunders PC, Guenther M, Rutherford P. 2013. Valuing environmental sustainability attributes of food products in India and China: decomposing the value of New Zealand's 'CleanGreen' brand.

Temkin A, Evans S, Manidis T, Campbell C, Naidenko OV. 2019. Exposure-based assessment and economic valuation of adverse birth outcomes and cancer risk due to nitrate in United States drinking water. Environmental Research 176(9):108442 DOI 10.1016/j.envres.2019.04.009.

Thompson RM, Townsend CR. 2000. New Zealand's stream invertebrate communities: an international perspective. New Zealand stream invertebrates: ecology and implications for management. New Zealand Limnological Society, Christchurch, New Zealand 1:53-74.

USEPA. 2019. Ecoregional nutrient criteria for rivers and streams. Available at https://www.epa. gov/nutrient-policy-data/ecoregional-nutrient-criteria-rivers-and-streams (accessed 2 February 2020).

Vinson MR, Baker MA. 2008. Poor growth of rainbow trout fed new zealand mud snails Potamopyrgus antipodarum. North American Journal of Fisheries Management 28(3):701-709 DOI 10.1577/M06-039.1.

Wacker A, Martin-Creuzburg D. 2012. Biochemical nutrient requirements of the rotifer Brachionus calyciflorus: co-limitation by sterols and amino acids. Functional Ecology 26(5):1135-1143 DOI 10.1111/j.1365-2435.2012.02047.x. 
Wagenhoff A, Clapcott JE, Lau KEMM, Lewis GD, Young RG. 2017a. Identifying congruence in stream assemblage thresholds in response to nutrient and sediment gradients for limit setting. Ecological Applications 27(2):469-484 DOI 10.1002/eap.1457.

Wagenhoff A, Liess A, Pastor A, Clapcott JE, Goodwin EO, Young RG. 2017b. Thresholds in ecosystem structural and functional responses to agricultural stressors can inform limit setting in streams. Freshwater Science 36(1):178-194 DOI 10.1086/690233.

Wagenhoff A, Townsend CR, Matthaei CD. 2012. Macroinvertebrate responses along broad stressor gradients of deposited fine sediment and dissolved nutrients: a stream mesocosm experiment. Journal of Applied Ecology 49(4):892-902 DOI 10.1111/j.1365-2664.2012.02162.x.

Wang L, Robertson DM, Garrison PJ. 2007. Linkages between nutrients and assemblages of macroinvertebrates and fish in wadeable streams: implication to nutrient criteria development. Environmental Management 39(2):194-212 DOI 10.1007/s00267-006-0135-8.

Weigel BM, Robertson DM. 2007. Identifying biotic integrity and water chemistry relations in nonwadeable rivers of Wisconsin: toward the development of nutrient criteria. Environmental Management 40(4):691-708 DOI 10.1007/s00267-006-0452-y.

Whitehead A. 2018. Spatial modelling of river water-quality state: incorporating monitoring data from 2013 to 2017. Christchurch, New Zealand. Available at https://environment.govt.nz/ publications/spatial-modelling-of-river-water-quality-state-incorporating-monitoring-data-from2013-to-2017/.

Winterbourn M, Gregson K, Dolphin C. 1989. Guide to the aquatic insects of New Zealand. Entomological Society of New Zealand Auckland. Clayton: CSIRO Publishing.

Winterbourn M, Rounick J, Cowie B. 1981. Are New Zealand stream ecosystems really different? New Zealand Journal of Marine and Freshwater Research 15(3):321-328 DOI 10.1080/00288330.1981.9515927.

Withers PJA, Jarvie HP. 2008. Delivery and cycling of phosphorus in rivers: a review. Science of the Total Environment 400(1-3):379-395 DOI 10.1016/j.scitotenv.2008.08.002.

Wright-Stow AE, Winterbourn MJ. 2003. How well do New Zealand's stream-monitoring indicators, the macroinvertebrate community index and its quantitative variant, correspond? New Zealand Journal of Marine and Freshwater Research 37(2):461-470 DOI 10.1080/00288330.2003.9517180.

Wurtsbaugh WA, Paerl HW, Dodds WK. 2019. Nutrients, eutrophication and harmful algal blooms along the freshwater to marine continuum. Wiley Interdisciplinary Reviews-Water 6(5):1-27 DOI 10.1002/wat2.1373.

Zhou B, Zheng B. 2008. Research on aquatic ecoregions for lakes and reservoirs in China. Environmental Monitoring and Assessment 147(1-3):339-350 DOI 10.1007/s10661-007-0125-1. 